\title{
Nutritional status of vitamin B12 on small group of dental students based on food frequency questionnaire
}

\author{
Izzatul Syafiqah Bt. Abd Samad*, Nanan Nur’aeny*, Erna Herawati* \\ *Department of Oral Medicine, Faculty of Dentistry, Universitas Padjadjaran Indonesia
}

\begin{abstract}
Vitamin B12 plays an important role in general cell metabolism. Vitamin B12 also essential for normal hematopoietic, importance in maintaining the integrity of nervous system and formation of nervous system. Even though vvitamin B12 is essential for good health, some people may not be getting enough intake of vitamin B12. The purpose of this research is to get information about the nutritional status of vitamin B12 on dental students based on food frequency questionnaire. Method used in this research were descriptive non experimental of 30 dental students from Faculty of Dentistry in Universitas Padjadjaran. All samples were given the food frequency questionnaire and recorded the amount of food were taken within 7 days. The consumption of vitamin B12 daily were calculated by using Nutrisurvey software. Among 30 students, there were 7 students who were in lack of consumption of vitamin B12, 14 students or almost half of them who were in normal level and 9 students who were in high level of vitamin B12 consumption. Conclusion: The nutritional status of vitamin B12 on small group of dental students based on food frequency questionnaire were mostly in normal level.
\end{abstract}

Keywords: Nutritional status, vitamin B12, dental students, food frequency questionnaire

\section{INTRODUCTION}

Nutritional status is the condition of health as it relates to food and nutrient intake, absorption, and utilization. ${ }^{1}$ A nutrient can be considered essential if it serves an indespensable physiologic function, but cannot be synthesized endogenously at adequate rate by healthy subjects. ${ }^{2}$ Nutrition is classified into micronutrients such as vitamin and mineral and macronutrients such as carbohydrate, protein and fat. ${ }^{3}$

Nevertheless, Indonesia is one of the country where has the highest nutrition problem among other ASEAN country. ${ }^{4}$ Recent studies have demonstrated that nutrition affects the student's thinking skills, behavior and health. ${ }^{5}$ There were few research which have been documented showed that nutrition problem is more related to deficiency of micronutrient especially vitamin B12, zinc, and folic acid. ${ }^{6}$

Vitamin $\mathrm{B} 12$ is a nutrient which includes a group of cobalt-containing compounds known as cobalamins, which are produced by microorganisms and are only found in foods. Vitamin B12 deficiency produces megaloblastic anemia, altered nucleic acid metabolism and neurologic damage (demyelinization) leading to subacute spinal cord degeneration and 
memory loss. No single symptom, or cluster of symptoms, has been uniquely associated with inadequate levels of vitamin B12. ${ }^{7}$ Although vitamin B12 deficiency is considered to be very rare in children, several reports have described dietary vitamin B12 deficiency in a young adult. ${ }^{7}$

There are few international researches which demonstrated about deficiency of vitamin B12 on university students. However, there is no public research that is conducted in Indonesia related about this matter. The purpose of this research is to get information about the nutritional status of vitamin B12 on dental students based on food frequency questionnai

\section{METHODS}

Total of 30 randomized dental students in Universitas Padjadjaran filled the informed consent form. Ethical approval was obtained from the The Health Research Ethics Committee Faculty of Medicine Universitas of Padjadjaran. All of them were given the Food Frequency form and checklist the amount of food consumption per day. After 7 days, the Food Frequency form were collected and calculated amount of Vitamin B12 by using the Nutrisurvey software. The result was gathered and classified into tables which consisted of high group, normal group and low group.

Table 1 Nutrient Intake by sample in a week

\begin{tabular}{|c|c|c|c|c|c|c|c|c|c|c|c|}
\hline \multirow{2}{*}{ No. } & \multirow{2}{*}{ Gender } & \multicolumn{9}{|c|}{ Amount of nutrient intake by samples in a week $(\mathrm{N}=30)$} & \multirow{2}{*}{$\begin{array}{c}\text { Total vitamin B12 } \\
\text { in a week }(\mu \mathrm{g})\end{array}$} \\
\hline & & bread & potato & chicken & fish & egg & milk & tofu & tempe & vegetables & \\
\hline 1. & $M(Q)$ & 2 & 0 & 5 & 6 & 2 & 0 & 2 & 2 & 14 & 16.9 \\
\hline 2 & F)R) & 5 & 2 & 4 & 4 & 6 & 8 & 8 & 8 & 2 & 24.2 \\
\hline 3 & $F(N)$ & 7 & 0 & 6 & 8 & 7 & 7 & 0 & 0 & 3 & 23.9 \\
\hline 4 & $F(S)$ & 7 & 0 & 5 & 5 & 0 & 14 & 3 & 3 & 14 & 17.9 \\
\hline 5 & $F(A Y)$ & 0 & 0 & 7 & 7 & 7 & 0 & 7 & 7 & 14 & 19.6 \\
\hline 6 & $\mathrm{~F}(\mathrm{HC})$ & 14 & 0 & 5 & 4 & 2 & 0 & 3 & 3 & 7 & 15.9 \\
\hline 7 & $M(H)$ & 0 & 0 & 5 & 5 & 11 & 0 & 0 & 0 & 2 & 18.1 \\
\hline 8 & $F(N F)$ & 3 & 0 & 8 & 6 & 0 & 0 & 2 & 2 & 1 & 15.6 \\
\hline 9 & $M(A)$ & 7 & 0 & 2 & 2 & 2 & 0 & 0 & 0 & 7 & 7.2 \\
\hline 10 & $\mathrm{~F}(\mathrm{SH})$ & 7 & 0 & 2 & 2 & 2 & 0 & 0 & 0 & 14 & 7.2 \\
\hline 11 & $F(A)$ & 0 & 0 & 10 & 4 & 0 & 0 & 2 & 2 & 14 & 14.6 \\
\hline 12 & $M(A L)$ & 2 & 0 & 3 & 2 & 2 & 0 & 0 & 0 & 7 & 9.6 \\
\hline 13 & $F(M)$ & 1 & 0 & 2 & 2 & 0 & 0 & 0 & 0 & 14 & 3.8 \\
\hline 14 & $\mathrm{~F}(\mathrm{JU})$ & 3 & 0 & 7 & 7 & 4 & 0 & 0 & 0 & 17 & 16.6 \\
\hline 15 & $F(J U R)$ & 2 & 0 & 2 & 2 & 2 & 0 & 2 & 2 & 14 & 7.2 \\
\hline 16 & $M(W)$ & 3 & 0 & 8 & 6 & 4 & 0 & 2 & 2 & 18 & 22.4 \\
\hline 17 & $F(E)$ & 7 & 4 & 7 & 7 & 7 & 5 & 0 & 0 & 21 & 26.7 \\
\hline 18 & $F(B)$ & 7 & 5 & 9 & 4 & 0 & 0 & 2 & 2 & 14 & 13.9 \\
\hline 19 & $M(N)$ & 0 & 0 & 3 & 2 & 0 & 0 & 0 & 0 & 21 & 4.5 \\
\hline 20 & $F(T)$ & 2 & 0 & 5 & 5 & 5 & 0 & 2 & 2 & 0 & 20.8 \\
\hline 21 & $F(B)$ & 2 & 0 & 10 & 4 & 0 & 2 & 2 & 2 & 13 & 15.2 \\
\hline 22 & $F(K)$ & 0 & 0 & 2 & 2 & 0 & 7 & 0 & 0 & 2 & 5.9 \\
\hline 23 & $M(B)$ & 3 & 0 & 8 & 6 & 5 & 0 & 0 & 0 & 0 & 21.3 \\
\hline 24 & $F(D)$ & 7 & 0 & 7 & 7 & 5 & 0 & 2 & 2 & 14 & 24.6 \\
\hline 25 & $F(E)$ & 2 & 0 & 4 & 4 & 4 & 2 & 2 & 2 & 14 & 17.8 \\
\hline 26 & $F(F)$ & 7 & 0 & 9 & 5 & 0 & 0 & 0 & 0 & 2 & 15.1 \\
\hline 27 & $F(N)$ & 3 & 0 & 8 & 4 & 2 & 0 & 0 & 0 & 3 & 13.8 \\
\hline 28 & $F(I)$ & 3 & 0 & 9 & 5 & 0 & 0 & 2 & 2 & 14 & 15.1 \\
\hline 29 & $\mathrm{~F}(\mathrm{FIT})$ & 3 & 0 & 10 & 4 & 2 & 0 & 0 & 0 & 1 & 15.2 \\
\hline 30 & $F(D)$ & 2 & 0 & 8 & 5 & 0 & 0 & 0 & 0 & 7 & 11.6 \\
\hline
\end{tabular}


Table 2. Grouping based on the amount of vitamin B12 intake in a week $(n=30)$

\begin{tabular}{cccc}
\hline Group & High & Normal & Low \\
\hline & $(>2.4 \mathrm{mcg})$ & $(2.4 \mathrm{mcg})$ & $(<2.4 \mathrm{mcg})$ \\
$\mathrm{n}$ & 9 & 14 & 7 \\
\hline
\end{tabular}

\section{RESULT}

All samples were observed and interviewed how amount of nutritional they would take for a week by using food frequency questionnaire and gather in the table below (Table 1).

After total vitamin in a week on all sample calculated, the amount of vitamin B12 in each sample was divided into three groups which were: high, normal and low level of vitamin B12 consumption groups, as established in the table below (Table 2).

\section{DISCUSSION}

Based on the Table 1, all samples are being interviewed and observed their meals for one week by using Food Frequency Form. Food Frequency form is the limited checklist of foods with a frequency response for subjects to report how much and often each item was consumed for a specified period time. ${ }^{8}$ In this research, it is used to know how much vitamin B12 was consumed by each research subject per day and to study the sufficiency-level of vitamin B12 in a person.

As theoretically, vitamin B12 is one of the micronutrient which is a group of water-soluble compounds that acts as "cofactor" or helpers in different enzyme systems in the body. Other than that, vitamin B12 helps build DNA material and important in the production of red blood cells, epithelial cells and in maintaining a healthy nervous system. ${ }^{8}$

The amount of vitamin B12 that have been consumed calculated by using Nutrisurvey software. This research showed that 7 students were in the low intake of Vitamin B12 group $(<2.4$ $\mathrm{mcg}$ ). The average daily requirement is $2-5 \mathrm{mcg}$ per day. The recommended dietary allowance (RDA) for Vitamin B12 is 2.4 mcg per day for adult males and females. Low intake of Vitamin B12 in these seven samples may due to low intake of proteins such as fish, chicken, eggs and milk products such as fermented soybean and tofu and may also due to lack of awareness of balanced diet. ${ }^{9}$ However, the limitation of this research is there is also another factor which may also contribute to the deficiency of Vitamin B12 is stress factor. Continuous stress causes students consumed less healthy nutrient intake and keep having a lot of 'unhealthy foods' compare to daily nutrient recommendation. ${ }^{10}$

\section{CONCLUSION}

The nutritional status of vitamin B12 on small group of dental students based on food frequency questionnaire were mostly in normal level.

\section{REFERENCES}

1. Vernetti-callahan D. Eating well for a healthy mouth. Dental Continuing Education Course (batch 301) [online]; 2013. p. 1-21.

2. Mischley LK. Conditionally essential nutrients: the state of the science. J Food Nutrit 2014:1:1-4.

3. Ariyani WD, Santoso M, Oginawati K, Diah DL, Damastuti E, Kurniawati S, et al. The application of NAA and ASS techniques on determination of daily dietary intake of $\mathrm{Ca}$, Fe and $\mathrm{Zn}$ in school-aged children in Bandung City. J Nuclear Scie Technol 2011Aug;12(2):95-104.

4. Dewi S, Gaol L. Sistem pakar mendeteksi gizi buruk pada balita berbasis web dengan menggunakan metode certainty factor. Pelita Informatika Budi Darma; 2013. p. 126.

5. Chahal JS, Raina SK, Sharma KK, Kaur N. How common is Vitamin B12 deficiency: A report on deficiency among healthy adults from a medical college in rural area of North West India. Int J Nutrit 2014:4(4):241-5.

6. Hidayati L, Hadi H, Kumara A. Kekurangan energi dan zat gizi merupakan faktor risiko kejadian stunted pada anak usia 1-3 tahun yang tinggal di wilayah kumuh perkotaan Surakarta. J Kesehatan 2010;1(Jun):89-104.

7. Mustafa MM, Al AA, Mousleh MM. Signs and symptoms of vitamin b12 deficiency and its impacts on student's academic performance. Int J Scie: Basic and Appl Res 2014:18(1):14350.

8. Butler BJ. B12 and the vegan diet all you need to know about vitamin B12 in. J Vegetarian 
and Vegan 2012:1(1):7-10.

9. Khan NF, Saeed M, Chaudhary S, Ghafoor F. Haematological parameters and recurrent aphthous stomatitis. J Coll Surgeons Pakistan 2013:23(2):124-7.
10. El Ansari WEl, Adetunji H, Oskrochi R. Food and mental health: Relationship between food and perceived stress and depressive symptoms among university students in the United Kingdom. Central Eur J Med 2014;22(2):90-7. 